\title{
Article \\ The Nexus between Environmental Impact and Agricultural Sector Linkages: A Case Study of Pakistan
}

\author{
Muhammad Jawad Sajid ${ }^{1, *(D)}$ and Muhammad Habib ur Rahman ${ }^{2,3}$ (D) \\ 1 School of Engineering Management, Xuzhou University of Technology, Xuzhou 221000, China \\ 2 Crop Science Group, Institute of Crop Science and Resources Conservation, University of Bonn, \\ 53012 Bonn, Germany; mhabibur@uni-bonn.de \\ 3 Department of Agronomy, MNS University of Agriculture, Multan 60650, Pakistan \\ * Correspondence: jawad.jaws@outlook.com or 11910@xzit.edu.cn; Tel.: +86-18852131376
}

check for updates

Citation: Sajid, M.J.; Rahman, M.H.u. The Nexus between Environmental Impact and Agricultural Sector Linkages: A Case Study of Pakistan. Atmosphere 2021, 12, 1200. https:// doi.org/10.3390/atmos12091200

Academic Editor:

Ioannis Charalampopoulos

Received: 15 August 2021

Accepted: 12 September 2021

Published: 16 September 2021

Publisher's Note: MDPI stays neutral with regard to jurisdictional claims in published maps and institutional affiliations.

Copyright: (c) 2021 by the authors. Licensee MDPI, Basel, Switzerland. This article is an open access article distributed under the terms and conditions of the Creative Commons Attribution (CC BY) license (https:// creativecommons.org/licenses/by/ $4.0 /)$.

\begin{abstract}
Agriculture has a substantial environmental impact. However, little research has been conducted on the relationship between agriculture's environmental impacts and linkages, particularly for the key agriculture-based Pakistani economy. Additionally, the literature on environmental linkages rarely estimates multiple types of linkages in a single study. This study fills these critical research gaps. The study estimates the land, water, nitrogen, and $\mathrm{CO}_{2}$ impacts and linkages of Pakistan's agriculture sector using an input-output model and the hypothetical extraction method. The results indicated that agriculture directly accounted for approximately $27 \%, 93 \%, 92 \%$, and $1 \%$ of Pakistan's total sectoral land, water, nitrogen, and $\mathrm{CO}_{2}$ impacts (LWNC), respectively. While the sector indirectly contributed almost $2 \%, 0.3 \%, 0.4 \%$, and $0.4 \%$ of Pakistan's total LWNC. The bulk of direct LWNC impacts were caused by agricultural purchases from downstream sectoral importers. The majority of the indirect LWNC impacts were induced by agriculture's re-imports. The agricultural purchases from the downstream sector of "Food and Beverages" induced the greatest environmental impact. To ensure sustainable agriculture, particularly in Pakistan, the agriculture sector's direct and indirect environmental impacts should be reduced not only through better management practices and technology, but also by focusing on intermediate sectoral sources of direct and indirect environmental impacts.
\end{abstract}

Keywords: agriculture sector; environmental impact; hypothetical extraction method; input-output model; sectoral linkage; sustainability

\section{Introduction}

Agriculture both causes and is affected by climate change [1,2]. Agriculture is important for economic growth, but it is also associated with significant environmental issues [3]. Agriculture's negative environmental impacts are significant, and they can include pollution, soil, water, and air contamination [4]. Years of industrial agriculture have had a significant negative impact on the environment, raising serious concerns about the future of the food supply [5]. The environmental impact of agriculture will make meeting the increased demand for agricultural production in the coming decades difficult [6]. This is because global climate change threatens to destabilize many of the natural systems that enable modern agriculture [6]. However, modern agriculture is partly to blame for the sustainability crisis [6]. Agriculture's intricate interconnections with the global economy, human communities, and biodiversity make it one of the most critical conservation frontiers on the planet [7]. The need for sustainable resource management is becoming more pressing [7]. As a result, understanding the nexus between various direct and indirect environmental impacts and agricultural sector linkages is becoming increasingly important. Comprehending direct and indirect environmental impacts and their linkages can assist policymakers in developing fair and effective policy approaches by focusing on the true inter- and intra-sectoral sources of the agriculture sector's massive environmental impacts. 
Agriculture is regarded as the economic backbone of Pakistan [8]. It is the most important sector of the Pakistani economy [9]. Agriculture accounts for 18.9\% of Pakistan's GDP and employs more than $42 \%$ of the country's total labor force [10]. Agriculture accounted for $47.1 \%$ of the total land area in 2018 [11]. All of these factors indicate that agriculture is a significant sector in Pakistan in terms of economic size and resource use, implying that the agricultural sector has a sizable environmental impact. With a high population growth rate and an anticipated high agricultural industrial product demand [10], it is inevitable that Pakistan's agriculture sector's direct and indirect environmental impact will grow significantly over time. To target the direct and indirect environmental impacts, an estimation and understanding of these impacts will be required. Understanding the direct and indirect environmental impacts, as well as the intermediate industrial relationships that drive these environmental impacts, may assist Pakistan in reducing the agriculture sector's environmental impacts effectively and efficiently. Which, in turn, can ensure Pakistan's agricultural sustainability.

Although government agencies, international bodies, and scholars routinely report on the environmental impacts of various nations' agriculture sectors, the industrial links that contribute to the creation of environmental impacts are rarely reported. Sectoral (industrial) linkages are defined as a sector's or industry's inter- and intra-sectoral reliance on inputs and outputs. The classical multiplier and the hypothetical extraction method (HEM) are primarily used to estimate industrial-environmental linkages [12]. The HEM is preferable to the classical multiplier because it isolates a specific sector from an economy and estimates the target sector's economic or environmental impact by comparing economic or environmental values before and after the target sector is removed [13]. The traditional or HEM approaches have primarily focused on the carbon, pollutants, energy, and water linkages between different nations, regions, or municipalities. However, the relationship between the intermediate sectoral or industrial environmental linkages and the direct and indirect environmental impacts is usually not estimated under both the classical multiplier and the HEM methods. Therefore, intermediate industrial linkages are also not classified according to their relationship with the direct or indirect sectoral or industrial impacts in the related literature. The direct environmental impact is defined in this study as the direct impact of a target sector's production activity. The direct environmental impact of the target sector, in our case, Pakistan's agriculture sector, is induced by the purchases from the downstream sectors and the target sector's internal use of its output. The indirect environmental impact is caused by the consumption (e.g., raw materials, semi-finished goods, utilities, and miscellaneous services) of a target sector. Therefore, naturally, the indirect environmental impact is induced by a target sector's imports from upstream sectors and by the reimports of a target sector.

Our study aims to fill these critical research gaps. To achieve the objectives of this study, we will modify the relatively advanced HEM by providing a categorization scheme for intermediate sectoral linkages based on their nexus with direct and indirect environmental impacts. These reclassified intermediate sectoral environmental linkages are then used to estimate Pakistan's agriculture sectors' direct and indirect land, water, nitrogen and $\mathrm{CO}_{2}$ impacts, and their contribution to Pakistan's total sectoral environmental impacts (the agriculture sector categorization in our analysis is based on conventional sector classifications (see [14])). According to the standard sector categorization, the agriculture sector in our study includes businesses primarily engaged in cultivating crops, rearing livestock, and other creatures from a farm, ranch, or their natural habitats [15]. However, in our study's context, agriculture does not include the 'fishing' industry, which is listed as a separate sector in Pakistan's national input-output (IO) tables given by the Eora global MRIO database. Figure 1 presents the conceptual framework of our modifications introduced to the HEM for the categorization of intermediate industrial linkages based on their relationship to direct and indirect sectoral environmental linkages. The remainder of the paper includes Section 2 on relevant literature on sectoral/industrial linkages and the environmental impacts of the agriculture sector. Materials and methods are presented in 
Section 3, followed by results in Section 4, discussion in Section 5, policy implications in Section 6, and conclusions in Section 7.

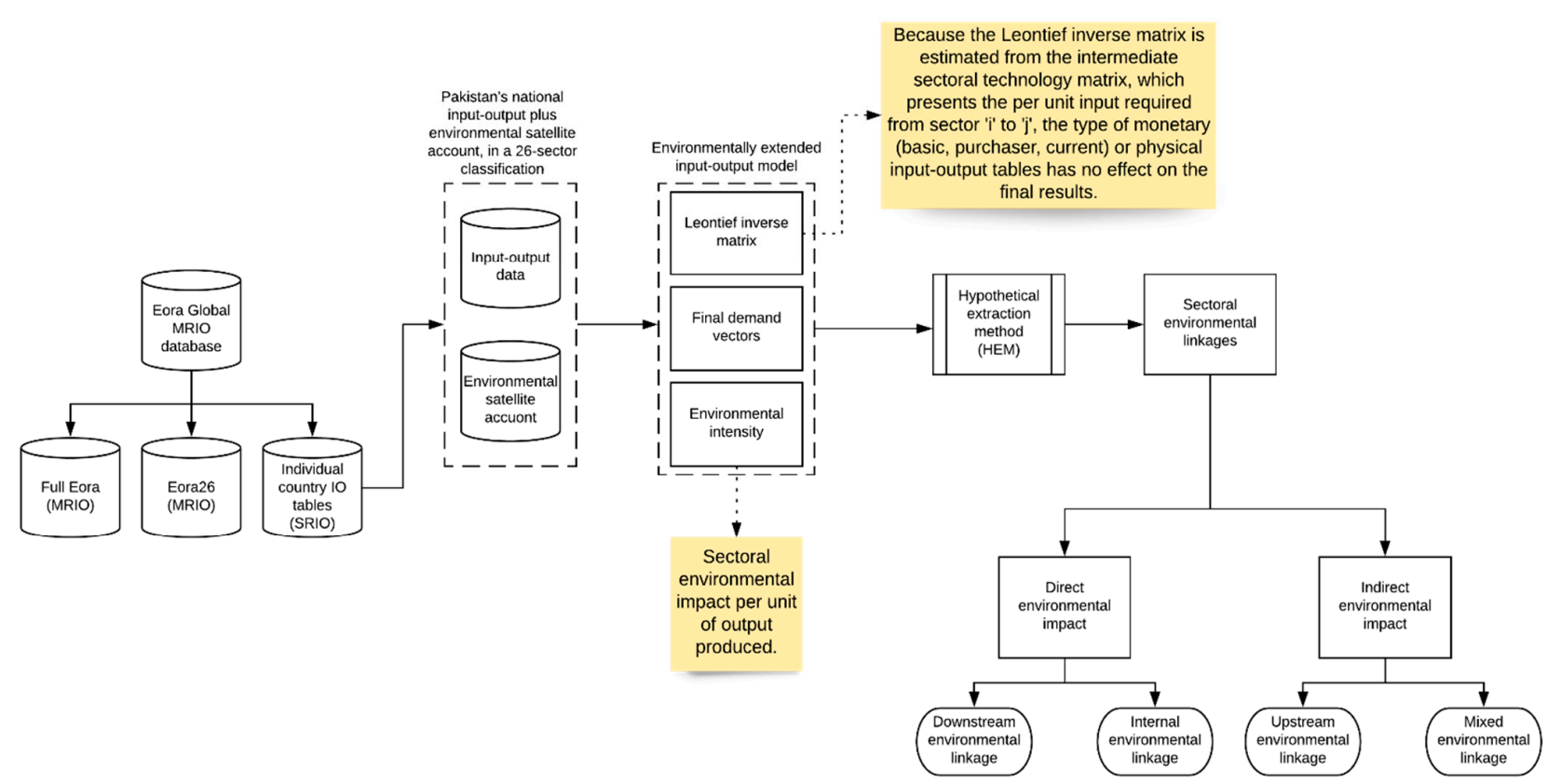

Figure 1. The flow chart of the methodology of our study. This flow chart shows how HEM, Eora MRIO, and the Pakistan database worked together and their contributions with regard to each part. As can be seen, the "Individual country IO tables" are used for this study. The "Individual country IO tables" provide Pakistan's national IO plus environmental satellite account, in a 26-sector classification. The Pakistani national IO table for the year 2015 is provided at basic and purchasers' prices. Some recent studies have preferred the use of basic prices [16,17]. However, as explained above, the selection of monetary (basic, purchaser or current prices) and physical type tables has no effect on intermediate sectoral technology. Therefore, the choice of basic or purchaser price does not impact the results estimated based on the IO data. Here, SRIO = Single regional IO, and MRIO = Multi-regional IO tables. The "environmental impact value" is defined and scaled based on the "Eora Satellite Accounts". The details about the definition and scaling procedure for each of the environmental impacts are explained in "Eora Satellite Accounts: Method and Data Notes", available at https:/ / worldmrio.com/IndicatorNotes.doc (accessed on 4 September 2021).

\section{Literature Review}

The most accurate way to quantify an environmental footprint is to quantify the area of biologically productive land and water required to generate the products consumed and to incorporate the wastes (such as greenhouse gases (GHG) and pollutant emissions) generated [18]. At the industrial level, an ecological footprint is typically composed of land, water, and emissions (air and carbon footprints) [19]. Pakistan, a country that is extremely climate vulnerable [13], is struggling on all three of these fronts. Pakistan is one of 36 countries suffering from water scarcity [20]. Agriculture is a major contributor to Pakistan's water crisis [20]. Converting natural areas to agriculture and other uses has significant environmental consequences. The term "land use" refers to how people utilize land. It depicts the economic and cultural activities (e.g., agricultural, residential, and industrial) that take place in a particular area. Out of a total of 79.6 million hectares of land area, cropped land in Pakistan accounted for 23.3 million hectares in 2018-2019 [21] and 23.67 million hectares in 2011-2012 [22]. Indicating that the agriculture sector in Pakistan has a sizable direct land footprint. Pakistan is one of the most polluted countries on the planet in terms of air pollution concentration [23]. Nitrogen oxides (NOx) are the primary component of air pollution, resulting in human deaths and loss of biodiversity [24]. Agriculture accounts for more than 70\% of global nitrogen emissions [25]. Thus, land, water, and air (both nitrogen and carbon) footprints can provide an accurate estimate of Pakistan's agricultural sector's ecological footprint. Understanding the inter- and intra- 
industrial environmental ramifications of Pakistan's agriculture sector's vital land, water (blue and grey water), nitrogen (nitrous oxides $\left(\mathrm{N}_{2} \mathrm{O}\right)$, ammonia $\left(\mathrm{NH}_{3}\right)$, nitrogen oxides $(\mathrm{NOx})$, nitrogen export in water $(\mathrm{N})$, nitric oxide $(\mathrm{NO})$, and nitrogen dioxide $\left.\left(\mathrm{NO}_{2}\right)\right)$, and $\mathrm{CO}_{2}$ impacts $\left(\mathrm{CO}_{2}\right.$ emissions from field operations [26] (for example, ridgers, plows, weeders, harrows, cultivators, skidding (clearing fields of logs and brush), planting, and harvesting [27]); $\mathrm{CO}_{2}$ emissions from on-farm transport [26]; $\mathrm{CO}_{2}$ emissions from urea and lime application to the soil [28] are some of the main sources of direct $\mathrm{CO}_{2}$ emissions in the agriculture sector. While upstream $\mathrm{CO}_{2}$ emissions from fertilizer and machinery manufacture [26] are instances of indirect upstream, $\mathrm{CO}_{2}$ emissions induced by agriculture sector imports) can aid in the effective and efficient reduction of the agricultural sector's environmental footprint.

Both the traditional multiplier and HEM methods can be used to assess the inter- and intra-sectoral environmental connections of a target sector. The classical multiplier sums the columns and rows of the direct input coefficient matrix to estimate backward and forward linkages. The conventional multiplier technique is incapable of computing the relative magnitude of sector effects, and the conventional multiplier, due to its propensity to ignore size differences between sectors, may provide misleading estimates of the relative strength of sector connections [29]. HEM compensates for this shortcoming by informing us of the sector's magnitude of influence on the carbon footprints of other sectors of the economy. The HEM is a refinement of the traditional multiplier approach; it increases the importance of a sector by removing its ties to the economic system; the sector's impact on economic activities can then be quantified by the output loss caused by the target sector's elimination; it is extremely beneficial to use the HEM in a multi-sectoral model to identify critical sectors for the economy [30]. HEM is further subdivided into Original, Cella, Modified HEM (MHEM), and Hybrid Modified HEM (HMHEM). Due to the deconstruction of intermediate sectoral connections into net forward, backward, internal, and mixed, the MHEM is preferred over the original and Cella's HEMs. Both the original and Cella's HEMs are unable to decompose intermediate sectoral connections into net environmental connections. On the other hand, despite overcoming some of the MHEM's theoretical and technological shortcomings, the most recent HMEM is still not widely used. This may be due to the fact that the HMHEM employs the relatively unknown Ghosh supply model in addition to the well-known Leontief demand model.

Using the HEM method, Duarte et al. estimated the sectoral water links in the Spanish economy [31]. Deng et al. estimated China's virtual water trade (industrial linkages) using the HEM approach [32]. Fang and Chen used the HEM method to estimate China's watercarbon sectoral links [33]. Using the HEM method, Dionisio et al. calculated the direct and indirect water productivity in Spain's "León" and "Castile" regions [34]. He et al. used the HEM to estimate the sectoral pollutant linkages for three major pollutants $\left(\mathrm{SO}_{2}\right.$, soot and dust) in China [35]. Wang et al. used the HEM technique to estimate China's interregional pollutant linkages [36]. Using the HEM, Deng et al. calculated China's sectoral energy links [37]. Using the HEM, Guerra and Sancho estimated the sectoral energy linkages in the Spanish economy [30]. Using the HEM approach, numerous studies have documented sectoral carbon linkages at the national [12,38-41] and international [42-44] levels. While studies such as [45-47] estimated sectoral carbon linkages using the traditional multiplier method, Sajid's study is the only one to date that has estimated Pakistan's sectoral carbon linkages using the HEM method [13]. In particular, various aspects of agriculture's environmental impact have been thoroughly researched in the related literature. Table 1 summarizes in broad categories some of the studies conducted on the environmental impacts of the agriculture sector. 
Table 1. A list of previous studies conducted on major aspects of the agriculture sector's environmental impacts.

\begin{tabular}{cc}
\hline Aspects of Environmental Impact & Study Scope and Major Findings \\
\hline Management practices & $\begin{array}{c}\text { The study compared the environmental performance of organic } \\
\text { and conventional farming. Their research showed that } \\
\text { organically maintained soils retain more water than } \\
\text { conventionally managed soils. Organic farming, with its } \\
\text { enhanced potential to retain carbon in the soil, might help } \\
\text { reduce } \mathrm{CO}_{2} \text { emissions if widely adopted. }\end{array}$ \\
\hline
\end{tabular}

A study on the learning of small-scale horticultural producers in Northeastern Brazil about their soils and how this translates Winstone et al. [49] into land management methods. Organic farmers with more information and training saw soil characteristics as key soil health indicators and had a more comprehensive interaction with the soil.

Farm/regional level impact

Werf et al. [50]

The study evaluated 12 indicator-based techniques for measuring agricultural environmental impact. Indicators based on the environmental consequences of farmer practices are superior to indicators based on farmer practices because the relationship with the goal is direct and the farmer has complete control over the means.

Almaraz et al. [24]

The study quantified NOx emissions from California's agricultural soils and established that agricultural soils constitute the state's primary source of NOx pollution.

Environmental impact assessment methods and platforms

Sabiha et al. [51]

The research created a "comprehensive environmental impact index (CEII)" to quantify the amount of agricultural environmental damage. The results indicated that between $27 \%$ and $69 \%$ of the theoretical maximum amount of environmental harm is caused by "High Yield Variety" rice production, with substantial regional differences in CEII scores.

The "Agri-environmental Footprint Index (AFI)" was presented in this study as a tool for assessing the existing condition of the

Dabkiene et al. [52] environment and tracking changes and accomplishments on farms. The most ecologically friendly farms were defined as medium-sized (economically speaking) and specialized on field crops-grazing animals.

Multiple categories of environmental impact and footprint

German et al. [53]

The authors performed a meta-analysis to examine the connections between several agricultural sustainability metrics. They provided significant evidence of a link between yields and the negative externalities caused by farming across a variety of metrics.

The article proposed an optimization model for the water-energy-food-environment nexus for agricultural

Yue and Guo [54] sustainability. The findings underlined the need of increasing internal water storage capacity, prudent agricultural management, and compromising choice preferences.

Pesticides and fertilizers environmental impact

Raliya et al. [55]

This paper presented an overview of smart and precision agriculture based on nanotechnology. 
Table 1. Cont.

\section{Aspects of Environmental Impact}

Chiew et al. [56]
Study Scope and Major Findings

The environmental effects of recycling plant nutrients from anaerobically digested food waste as fertilizer in agriculture were investigated in this study. In all categories evaluated, the use of digested food waste as fertilizer had more negative outcomes than the use of chemical fertilizer, with the exception of the usage of non-renewable phosphate rock.

Life cycle assessment

Jiang et al. [57]

The environmental performance of wheat production utilizing four different fertilizer techniques was examined in this study using the life cycle assessment (LCA) method. When coupled with the findings of the sensitivity analysis, the most significant hotspots contributing to negative environmental effects were found as "biogenic air pollutant emissions" from the compost and biochar synthesis stages.

Using a Life Cycle Assessment (LCA) and a case study of a circular agricultural industry firm in Xingyuan, Fuqing, this article evaluated the potential implications of a circular

Fan et al. [58] agriculture model against a traditional agriculture industrial model. Circular agriculture did not outperform traditional agriculture when only probable environmental implications were considered.

Technology

The authors created a "Economic and Environmental Impact" analytical framework to investigate the economic and environmental implications of applying "Technologies and management practices (TMPs)" in agriculture. The findings revealed that the impact of TMPs on farmers' economic decisions and the environment is influenced by how TMPs modify the yield ceiling and the $\mathrm{N}$ fertilization rate at the ceiling, as well as how TMP, fertilizer, and crop prices fluctuate.

Waste

The study examined how to conduct a step-by-step evaluation in order to develop biorefinery configurations depending on feedstock compatibility and implementation location. The findings indicated that agricultural waste systems do not Nilsson et al. [60] always result in environmental advantages, particularly when environmental impacts are quantified holistically, i.e., through monetizing environmental damages.

Policy

This study used game theory to analyze the impact of three subsidy schemes in an agricultural supply chain composed of a low-cost company and a high-cost enterprise. The findings demonstrated that neither the output quantity subsidy nor the environmental innovation subsidy can address the conflict between agricultural growth and environmental conservation on their own.

Although various aspects of the agricultural sector's environmental impact have been studied in depth, the nexus between different environmental impacts and agricultural sector linkages has received little attention in the related literature. Second, the decomposition of the agricultural sector's direct and indirect environmental impacts is not well researched in the related literature. Third, the environmental linkage literature generally does not distinguish between the linkages that induce (drive) direct sectoral environmental 
impacts and the linkages that drive indirect sectoral environmental impacts. Fourth, most of the environmental linkage literature does not present several major sectoral (industrial) environmental linkages in a single study. Rather, one or two environmental connections are typically presented in related studies. Finally, the environmental linkages of the agriculture sector, specifically in relation to direct and indirect environmental impacts on a major agriculture-based economy like Pakistan, are not discussed in the related literature.

This research fills some critical research gaps in the related literature. First, this study provides a detailed analysis of the relationship between various environmental impacts (land, water, nitrogen, and $\mathrm{CO}_{2}$ ) and agricultural sector linkages. Second, this study divides direct and indirect environmental impacts into inter- and intra-sectoral linkages that drive direct and indirect environmental impacts. To do so, the study remodifies the famous MHEM method to reclassify the net forward (downstream), net backward (upstream), internal and mixed (reimports) related environmental linkages in accordance with their relationship with direct and indirect environmental impacts. That, as evident from the above literature review, is not usually considered for the industrial (sectoral) environmental linkages literature under both the classical and HEM approaches. Third, this study introduces a theoretical and empirical framework for classifying sectoral (industrial) environmental linkages based on their impact on direct and indirect sectoral (industrial) environmental impacts. Fourth, the study simultaneously estimates the agriculture sector's critical land, nitrogen (air), water, and carbon linkages. Fifth, the study examines the case of Pakistan, a major agriculture-based economy, and estimates the nexus between its agriculture sector's direct and indirect environmental impacts and linkages.

Pakistan expects a high population growth rate and high agricultural industrial product demand [9], implying that if necessary actions are not taken, both the direct and indirect environmental impact of Pakistan's agriculture sector will increase significantly over time. The presentation of the nexus between direct and indirect environmental impacts of a major agriculture-based economy like Pakistan will not only assist the Pakistani government in particular, but other policymakers in general, in looking beyond conventional measures, by diversifying mitigation measures between different sources of the agriculture sector's direct and indirect environmental impacts. In addition, the presentation of the theoretical concept and empirical estimation method for estimating the inter- and intra-sectoral (industrial) linkages driving direct and indirect environmental impacts can advance the literature on related theories and methodologies. The theory and methodology proposed in this study can be used to estimate the relationship between direct and indirect sectoral impacts and linkages in general.

\section{Materials and Methods}

\subsection{Data Sources}

This study uses Pakistan's "individual country input-output tables" and environmental footprint accounts for 2015 from the Eora MRIO [62,63]. Eora global MRIO provides individual country (national) and multi-regional IO tables, as well as environmental indicators such as land, water, air, and carbon footprints for 190 countries from 1995 to 2015 . The Eora MRIO provides IO tables for basic and purchase prices. In this study, the basic price IO tables (Unit = '000' US dollar) are used, but as shown in Figure 1, the choice between basic and purchasers does not affect the final results. For this study, the total land use is calculated by summing up different types of land use, particularly by summing the row entries 2449-2543, 2457, 2461, and 2469 from the EORA national IO database. The blue and grey water footprints are calculated using row entries 2501 and 2502. The nitrous oxides $\left(\mathrm{N}_{2} \mathrm{O}\right)$, ammonia $\left(\mathrm{NH}_{3}\right)$, nitrogen oxides $(\mathrm{NOx})$, and nitrogen export in water $(\mathrm{N})$ are calculated using row entries 2470 and 2472-2474, and the total $\mathrm{CO}_{2}$ emissions are calculated using row entry 2608. The NOx footprint is equal to the $\mathrm{NO}+\mathrm{NO}_{2}$ footprint [24]. The Eora MRIO is frequently used for various environmental footprint issues, such as water [64], air pollution [65], and carbon emissions [13]. 


\subsection{Methodology}

\subsubsection{Direct Environmental Impact Estimation}

Traditionally, the "Wassily Wassilyevich Leontief" IO model is used to estimate various types of environmental footprints [66]. The following equations illustrate the IO method for estimating Pakistan's agricultural sector's direct land, water, nitrogen and carbon footprints.

$$
E F_{i}^{t}=e_{i}^{t}(I-A)^{-1} C_{i}
$$

where $E F_{i}^{t}$ denotes sector $i^{\prime}$ s type $t$ direct environmental impact. Here $t$ presents the land, water, nitrogen, and carbon impacts. $e_{i}^{t}$ show the sector $i^{\prime}$ 's per-output-unit land use (the total land footprint is calculated as the sum of "fallow land (temporary), forest, inland water, land area, other land, permanent crops, permanent meadows and pastures, and total area equipped for irrigation"), water use, nitrogen emissions, and carbon discharges. $(I-A)^{-1}$ denotes the Leontief inverse matrix, which is commonly abbreviated by $L$. Additionally, $C_{i}$ denotes the sector $i^{\prime} s$ final consumption. The value of $e_{i}^{t}$ is approximated as follows.

$$
e_{i}^{t}=\frac{E F_{i}^{t}}{T_{i}}
$$

where $T_{i}$ presents the total output of sector $i$. The above-mentioned equation number 1 can be modified to present the decomposed water and nitrogen impacts.

\subsubsection{Classification of the Economy into Target and Non-Target Sectors}

For simplicity, an economy can be represented by only two sectors: the target sector $g$, whose inter- and intra-sectoral environmental linkages must be measured, and the other non-target sectors $-g$, which represent the rest of the economy's sectors. The environmental impacts of the resulting two-sector economy are shown below.

$$
E F^{t}=\left[\begin{array}{cc}
e_{g}^{t} & 0 \\
0 & e_{-g}^{t}
\end{array}\right]\left[\begin{array}{cc}
\left(I-A_{g, g}\right)^{-1} & \left(I-A_{g,-g}\right)^{-1} \\
\left(I-A_{-g, g}\right)^{-1} & \left(I-A_{-g,-g}\right)^{-1}
\end{array}\right]\left[\begin{array}{c}
C_{g} \\
C_{-g}
\end{array}\right]=\left[\begin{array}{cc}
e_{g}^{t} & 0 \\
0 & e_{-g}^{t}
\end{array}\right]\left[\begin{array}{cc}
l_{g, g} & l_{g,-g} \\
l_{-g, g} & l_{g, g}
\end{array}\right]\left[\begin{array}{c}
C_{g} \\
C_{-g}
\end{array}\right]
$$

where $E F^{t}$ denotes an economy's type $t$ environmental impact. $W F^{p}$ and $O F^{p}$ denote the type $p$ water and nitrogen impacts, respectively. $\left[\begin{array}{cc}e_{g}^{t} & 0 \\ 0 & e_{-g}^{t}\end{array}\right]$ denotes an economy's perunit use of resources like land and water resources, as well as per unit nitrogen and carbon emissions from the target sector and non-target sectors. $L=\left[\begin{array}{cc}l_{g, g} & l_{g,-g} \\ l_{-g, g} & l_{g, g}\end{array}\right]$ represents the Leontief inverse matrix with two sectors, namely the target sector $g$ and the remainder of the sectors in a region or nation. $\left[\begin{array}{c}C_{g} \\ C_{-g}\end{array}\right]$ depicts the final consumption (demand) of the products offered by the target sector $g$ and the rest of the economy's sectors $-g$.

\subsubsection{Hypothetical Extraction Method (HEM)}

The Cella hypothetical extraction method [67] eliminates the target sector's external linkages from an economy and then compares the effect of the target sector's external linkages on the economy by comparing the before and after values [41,42]. The following equations illustrate the process of removing external linkages from the target sector.

$$
E^{\prime} F^{t}=\left[\begin{array}{cc}
e_{g}^{t} & 0 \\
0 & e_{-g}^{t}
\end{array}\right]\left[\begin{array}{cc}
\left(I-A_{g, g}\right)^{-1} & 0 \\
0 & \left(I-A_{-g,-g}\right)^{-1}
\end{array}\right]\left[\begin{array}{c}
C_{g} \\
C_{-g}
\end{array}\right]
$$

where $E F^{t}$ represent an economy's $t$ type environmental footprint, without the target sector's external environmental linkages. The following equations depict the impact of the target sector's external environmental linkages on an economy's environmental linkages. 


$$
\Delta E F^{t}=E F^{t}-E^{\prime} F^{t}=\left[\begin{array}{cc}
e_{g}^{t} & 0 \\
0 & e_{-g}^{t}
\end{array}\right]\left[\begin{array}{cc}
l_{g, g}-\left(I-A_{g, g}\right)^{-1} & l_{g,-g} \\
l_{-g, g} & l_{g, g}-\left(I-A_{-g,-g}\right)^{-1}
\end{array}\right]\left[\begin{array}{c}
C_{g} \\
C_{-g}
\end{array}\right]
$$

\subsubsection{Modified Hypothetical Extraction Method (MHEM)}

The modified hypothetical extraction method (MHEM) proposed by Duarte et al. is based on Cella's HEM [31]. The MHEM calculates the net environmental linkages between various types of environmental footprints. The model divides sectoral linkages into net backward, internal, net forward, and mixed linkages. Here, the linkage definitions and terminology have been simplified to convey the concept of various environmental linkages. The upstream sectoral environmental links (indirect environmental footprints) illustrate the resources consumed (i.e., land or water) or emissions generated (i.e., nitrogen and carbon discharges) in supplying the target sector's input (products or services). The downstream environmental linkages illustrate how the target sector uses resources and generates emissions to meet demand from other sectors of the economy. Internal environmental linkages depict the resource consumption and emission generation associated with the target sector's intra-sectoral demand for its own products or services. Finally, the mixed environmental linkages illustrate the resource consumption and emission generation associated with the re-imports of the target sector.

\subsubsection{Decomposition of Direct Environmental Impact via MHEM}

The direct environmental impact reflects how a sector's operations directly affect the environment. According to this definition, direct sectoral environmental impact can be embedded into the direct environmental impact induced by downstream sector purchases. Additionally, the direct impact on the environment caused by a sector's internal consumption of its own output.

Downstream environmental linkage

$$
D E F_{g}^{t}=e_{g}^{t}\left(l_{g,-g}\right) C_{-g}
$$

Internal environmental linkage

$$
I E F_{g}^{t}=e_{g}^{t}\left(l_{g, g}\right) C_{g}
$$

The direct environmental impact of the agricultural sector is presented by the following equations.

$$
R E F_{g}^{t}=D E F_{g}^{t}+I E F_{g}^{t}=e_{g}^{t}\left(l_{g,-g}\right) C_{-g}+e_{g}^{t}\left(l_{g, g}\right) C_{g}
$$

where $R E F_{g}^{t}$ presents the $t$ type direct environmental impact of sector $g$.

\subsubsection{Decomposition of Indirect Environmental Impact via MHEM}

The agriculture sector's indirect environmental impact represents the upstream environmental impact caused by the sector's demand for inputs. According to this definition, the sum of upstream and (imports) mixed (reimports) environmental linkages represent the sector's indirect environmental impact (hazard). The following equations illustrate how upstream and mixed environmental linkages are estimated.

Upstream environmental linkage

$$
U E F_{g}^{t}=e_{-g}^{t}\left(l_{-g, g}\right) C_{g}
$$

Mixed environmental linkage

$$
M E F_{g}^{t}=e_{g}^{t}\left(l_{g, g}-\left(I-A_{g, g}\right)^{-1}\right) C_{g}
$$


The indirect environmental impact of the agriculture sector can be presented via the following equations.

$$
I E F_{g}^{t}=U E F_{g}^{t}+M E F_{g}^{t}=e_{-g}^{t}\left(l_{-g, g}\right) C_{g}+e_{g}^{t}\left(l_{g, g}-\left(I-A_{g, g}\right)^{-1}\right) C_{g}
$$

where $I E F_{g}^{t}$ presents the $t$ type indirect environmental impact of sector $g$.

\subsubsection{Further Decomposition of Upstream and Downstream Linkages}

The agriculture sector's upstream and downstream linkages can be further decomposed into the sector-wise sources of the upstream and downstream environmental footprints. Where sector $j(j=1,2,3 \cdots, n-1)$ is one of the sectors, other than the target sector $g$.

$$
\begin{aligned}
& D E F_{g}^{t}=\sum_{j=1}^{n-1} e_{g}^{t}\left(l_{g, j}\right) C_{j} \\
& U E F_{g}^{t}=\sum_{j=1}^{n-1} e_{j}^{t}\left(l_{j, g}\right) C_{g}
\end{aligned}
$$

\subsubsection{Total Environmental Impact}

The total environmental impact of the agriculture sector is defined as the sum of all indirect and direct environmental impacts of the agriculture sector. That is, the total environmental impact of the agriculture sector is defined as the environmental hazard caused directly and indirectly by agricultural operations.

$$
E F^{t}=D E F_{g}^{t}+I E F_{g}^{t}
$$

\section{Results}

\subsection{Direct Environmental Impact}

Table 2 represents the percentage contributions of agriculture sector's total direct environmental impacts, intra-sectoral use, and downstream environmental impacts on total sectoral linkages of Pakistan. As shown in Table 2, the agriculture sector has a significant direct environmental impact in comparison to Pakistan's total environmental impact. The agriculture sector accounted for nearly a quarter of Pakistan's total sectoral land impact. While, the agriculture sector was responsible for nearly 93\% of Pakistan's total sectoral water impact. The sector accounted for approximately 99\% of Pakistan's blue water and nearly $78 \%$ of the country's total sectoral grey water impact. Agriculture accounted for nearly 92\% of Pakistan's total nitrogen impact. This sector accounted for nearly $90 \%$ of Pakistan's $\mathrm{NO}_{2}, 99 \%$ of $\mathrm{NH}_{3}, 15 \%$ of $\mathrm{NOx}$, and nearly $99 \%$ of $\mathrm{N}$ emissions. Finally, agriculture accounted for more than $1 \%$ of Pakistan's total sectoral $\mathrm{CO}_{2}$ emissions. Overall, downstream demand for agricultural sector output accounted for nearly $60 \%$ of the agriculture sector's direct environmental impact. 
Table 2. The contribution of Pakistan's agriculture sector's direct environmental impacts and sectoral linkages to total environmental impact of Pakistan.

\begin{tabular}{cccc}
\hline Item ${ }^{\mathbf{1}}$ & $\begin{array}{c}\text { Downstream Environmental } \\
\text { Linkage (\%) }\end{array}$ & $\begin{array}{c}\text { Internal Environmental } \\
\text { Linkage (\%) }\end{array}$ & $\begin{array}{c}\text { Total Direct Environmental } \\
\text { Impact (\%) }\end{array}$ \\
\hline Land & 16.7 & 10.0 & 26.7 \\
Water & 58.3 & 35.0 & 93.3 \\
Blue water & 61.9 & 37.2 & 99.0 \\
Grey water & 48.7 & 29.2 & 77.9 \\
Nitrogen impact & 57.3 & 34.4 & 91.7 \\
$\mathrm{~N}_{2} \mathrm{O}$ & 56.5 & 33.9 & 90.4 \\
$\mathrm{NH}_{3}$ & 61.9 & 37.2 & 99.0 \\
$\mathrm{NOx}$ & 9.2 & 5.5 & 14.7 \\
$\mathrm{~N}$ & 62.1 & 37.3 & 99.4 \\
$\mathrm{CO}_{2}$ & 0.9 & 0.5 & 1.4 \\
\hline
\end{tabular}

${ }^{1}$ Pakistan's total sectoral environmental impact is estimated as the sum of all sector environmental impacts from the 2015 IO table available at: https:/ / worldmrio.com/ (accessed on 26 March 2021).

\subsection{Indirect Environmental Impact}

Table 3 shows the percentage contributions of agriculture sector's total indirect environmental impacts, mixed, and upstream environmental impacts on total sectoral linkages of Pakistan. In comparison to Pakistan's total sectoral environmental impact, the agricultural sector's indirect environmental impact was marginal. The indirect land and nitrogen oxides accounted for the majority of agriculture's indirect environmental impact, accounting for approximately $2 \%$ and $1 \%$, respectively. Backward and mixed linkages did not contribute equally to total indirect environmental impacts. The majority of the indirect environmental impacts were caused by mixed linkages. However, for $\mathrm{NO}_{\mathrm{X}}$ and $\mathrm{CO}_{2}$ emissions, upstream linkages accounted for approximately $93 \%$ and $99 \%$ of indirect environmental impacts, respectively.

Table 3. The contribution of Pakistan's agriculture sector's indirect environmental impacts and sectoral linkages to total environmental impact of Pakistan.

\begin{tabular}{cccc}
\hline Item & $\begin{array}{c}\text { Upstream Environmental } \\
\text { Linkage (\%) }\end{array}$ & $\begin{array}{c}\text { Mixed Environmental Linkage } \\
\mathbf{( \% )}\end{array}$ & $\begin{array}{c}\text { Total Indirect Environmental } \\
\text { Impact (\%) }\end{array}$ \\
\hline Land & 0.24 & 1.24 & 1.48 \\
Water & 0.01 & 0.30 & 0.31 \\
Blue water & 0.00 & 0.32 & 0.32 \\
Grey water & 0.03 & 0.25 & 0.28 \\
Nitrogen impact & 0.04 & 0.29 & 0.35 \\
$\mathrm{~N}_{2} \mathrm{O}$ & 0.03 & 0.26 & 0.28 \\
$\mathrm{NH}_{3}$ & 0.00 & 0.32 & 0.32 \\
$\mathrm{NOx}$ & 0.48 & 0.03 & 0.51 \\
$\mathrm{~N}$ & 0.002 & 0.32 & 0.32 \\
$\mathrm{CO}_{2}(\mathrm{Gg})$ & 0.37 & 0.005 & 0.38 \\
\hline
\end{tabular}

\subsection{Total Environmental Impact}

Table 4 presents the contributions of total environmental impacts of the Pakistani agriculture sector to the total sectoral environmental impacts of Pakistan. Figure 2 depicts a comparison of the direct and indirect environmental impacts of Pakistan's agriculture sector. The agriculture sector's contribution (direct and indirect) to Pakistan's total sectoral environmental impact was substantial. This sector directly and indirectly contributed to approximately $28 \%$ of Pakistan's total environmental impact from land use. Approximately $94 \%, 99 \%$, and $78 \%$ of total water, blue, and grey impacts and $92 \%, 91 \%, 99 \%, 15 \%$, and $99.7 \% \mathrm{~N}_{2} \mathrm{O}, \mathrm{NH}_{3}, \mathrm{NOx}$, and $\mathrm{N}$ impacts, respectively. Additionally, $2 \%$ of $\mathrm{CO}_{2}$ emissions. As shown in Figure 2, the agricultural sector's direct environmental impacts account for the 
majority of its total environmental impacts. In comparison to other indirect environmental impacts, the agriculture sector's indirect carbon emissions and land use impacts were the most significant, accounting for approximately $21 \%$ and $5 \%$ of total environmental impacts, respectively.

Table 4. The contribution of Pakistan's agriculture sector's total (direct + indirect) environmental impacts to Pakistan's total sectoral environmental impacts.

\begin{tabular}{cc}
\hline Item & Total \% Environmental Impact (Direct + Indirect) \\
\hline Land & 28 \\
Water & 94 \\
Blue water & 99 \\
Grey water & 78 \\
Nitrogen impact & 92 \\
$\mathrm{~N}_{2} \mathrm{O}$ & 91 \\
$\mathrm{NH}_{3}$ & 99 \\
$\mathrm{NOx}$ & 15 \\
$\mathrm{~N}$ & 100 \\
$\mathrm{CO}_{2}$ & 2 \\
\hline
\end{tabular}

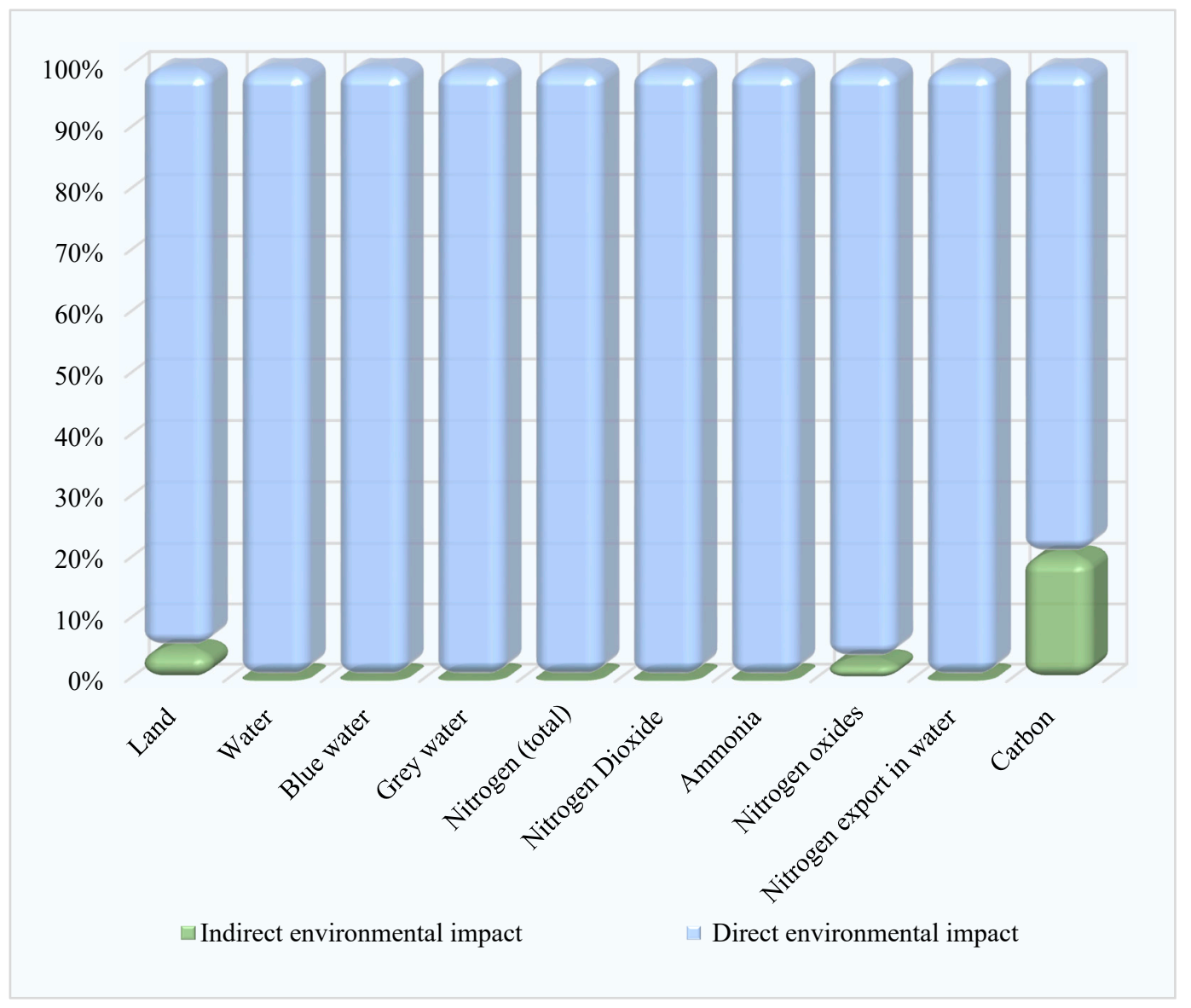

Figure 2. A comparison of Pakistan's agriculture sector's total direct and indirect environmental impacts.

\subsection{Further Decomposition of Downstream and Upstream Environmental Impacts}

Figure 3 represents the decomposed environmental linkages of Pakistan's agriculture sector. Purchases by the "Food and Beverage", "Textiles and Wearing Apparel", and "Hotels and Restaurants" sectors were responsible for the majority of the agriculture sector's downstream environmental impact. In other words, these three sectors were the 
primary inter-sectoral customers, accounting for a significant portion of Pakistan's direct environmental impact. Inter-sectoral imports of "Electricity, Gas, and Water", "Financial Intermediation and Business Activities", and "Petroleum, Chemical, and Non-Metallic Mineral Products", on the other hand, accounted for the majority of the agriculture sector's indirect upstream $\mathrm{CO}_{2}$ emissions. The largest indirect land impact by purchases (upstream linkages) of the agriculture sector was induced by "Financial Intermediation and Business Activities", "Petroleum, Chemical and Non-Metallic Mineral Products", and "Wholesale Trade", respectively. The main upstream sources of indirect nitrogen emissions impact were "transportation", "electricity, gas, and water", and "food and beverages". The largest indirect water use impact was attributed to "Petroleum, Chemical, and Non-Metallic Mineral Products", "Food and Beverages", and "Mining and Quarrying".

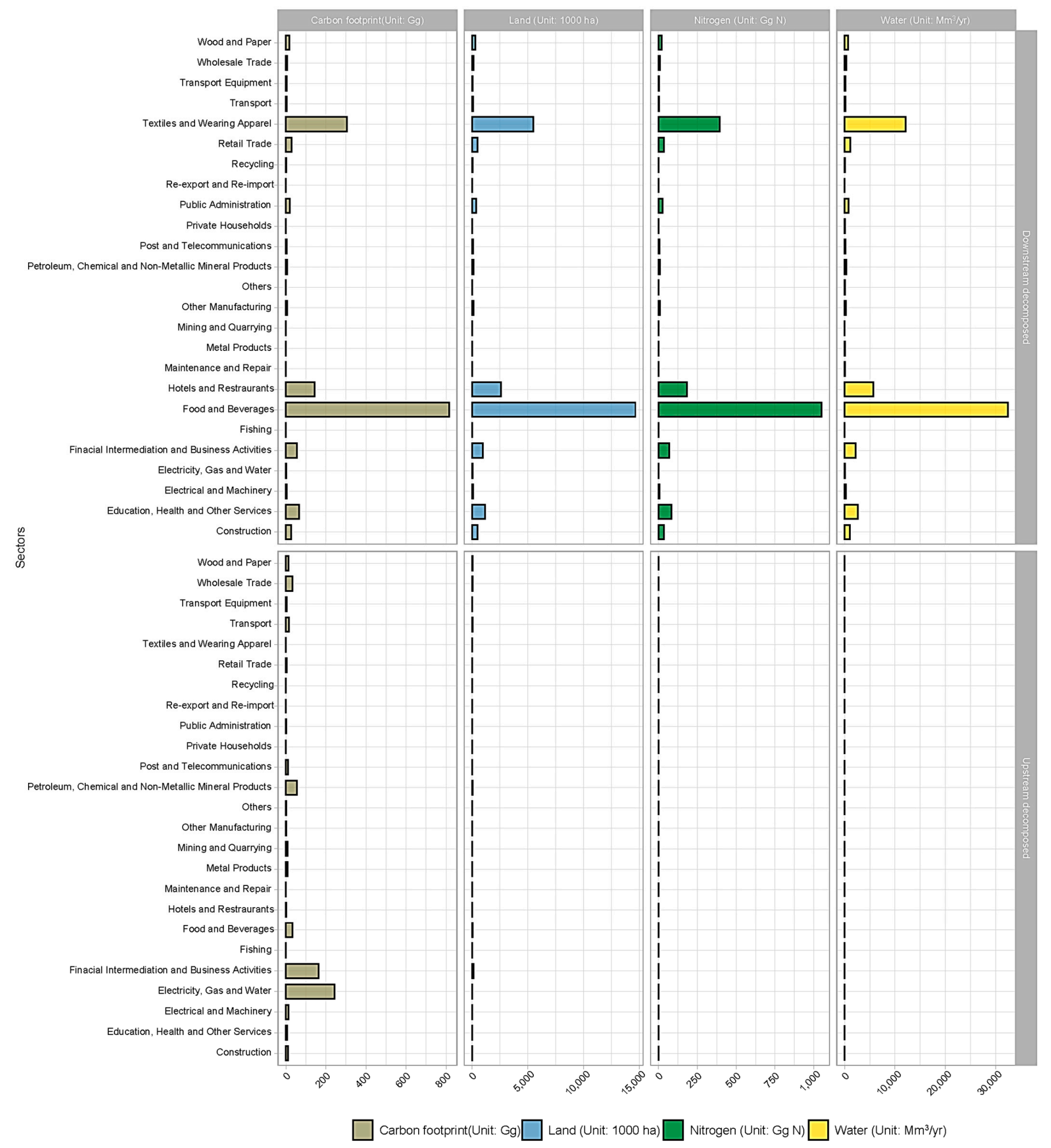

Figure 3. Agriculture sector's decomposed upstream and downstream environmental impacts. 
Figure 4 illustrates the further decomposition of the agriculture sector's water use and nitrogen emissions impacts in Pakistan. Again, downstream purchases from the sectors of "Food and Beverage", "Textiles and Wearing Apparel", and "Hotels and Restaurants" had the greatest impact on blue and grey water usage, as well as the agricultural sector's $\mathrm{N}_{2} \mathrm{O}, \mathrm{NH}_{3}, \mathrm{NOx}$, and $\mathrm{N}$ discharges. The sector of "Petroleum, Chemical, and Non-Metallic Mineral Products" had the greatest indirect upstream blue and grey water use impacts. Finally, for $\mathrm{N}_{2} \mathrm{O}, \mathrm{NH}_{3}, \mathrm{NOx}$, and $\mathrm{N}$ emissions, the largest sources of indirect upstream impacts were "Financial Intermediation and Business Activities", "Mining and Quarrying", "Transport", and "Food and Beverages".

(a) Water use impact: Upstream decomposed

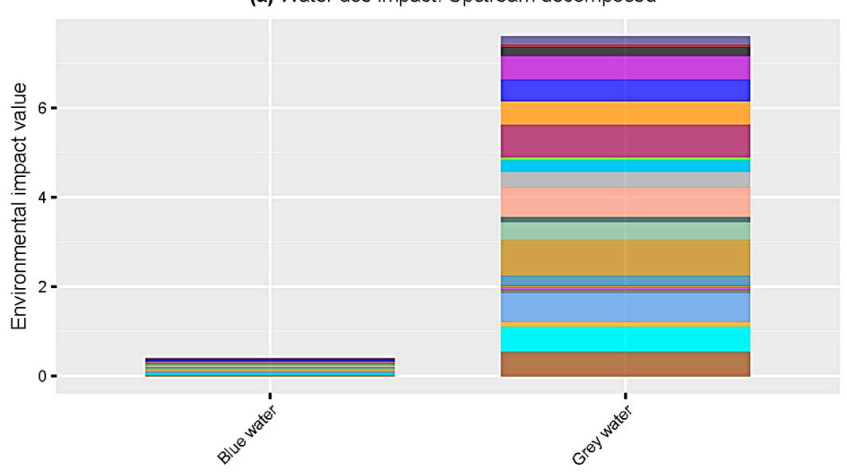

(c) Nitrogen emissions: Upstream decomposed

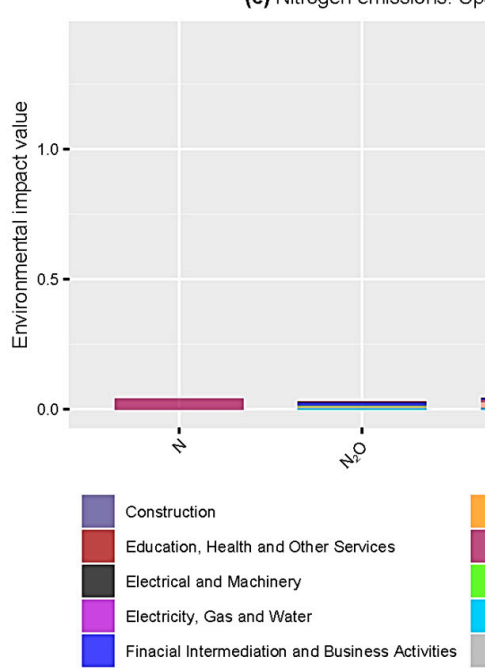

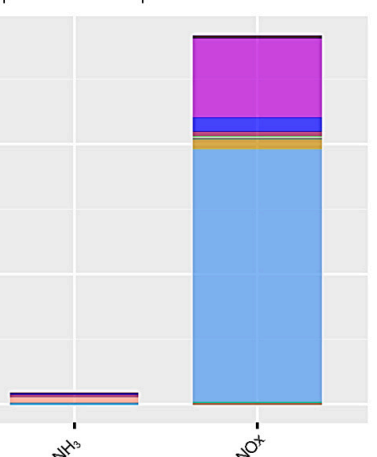

$\mathrm{sin}_{0}$ Fishing

Food and Beverages Hotels and Restraurants Maintenance and Repair Metal Products

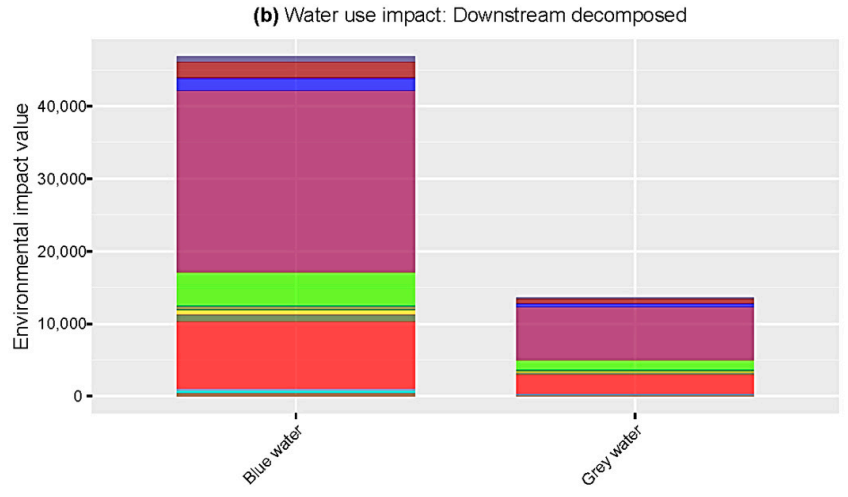

(d) Nitrogen emissions: Downstream decomposed

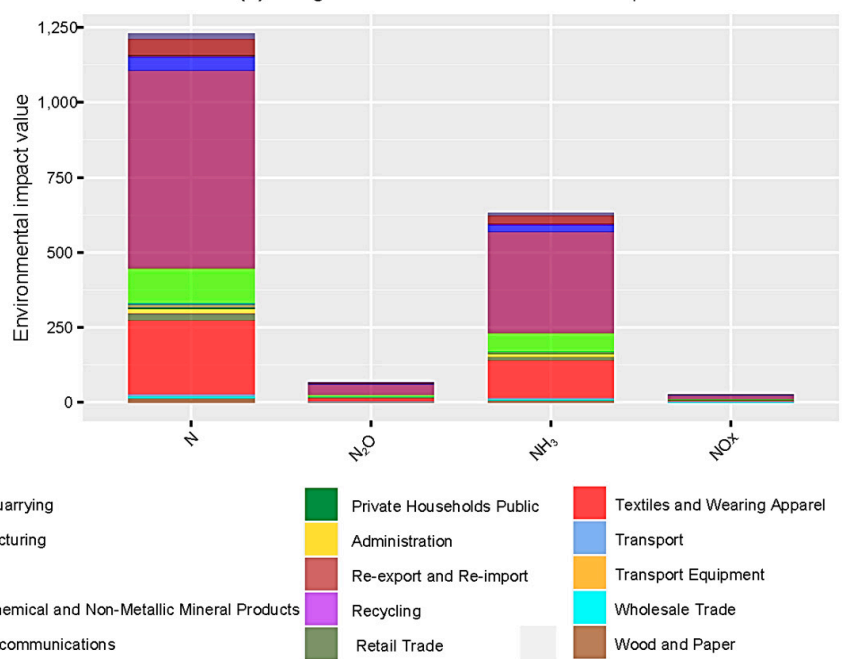

Figure 4. Further decomposition of water and nitrogen linkages of the agriculture sector. Here, the unit of nitrogen emissions is ' $\mathrm{Gg} \mathrm{N}$ ' and for the water use is ' $\mathrm{Mm}^{3} / \mathrm{yr}^{\prime}$. (a) Water use impact: Upstream decomposed, (b) Water use impact: Downstream decomposed, (c) Nitrogen emissions: Upstream decomposed, (d) Nitrogen emissions: Downstream decomposed.

\section{Discussion}

The agriculture sector alone had a direct environmental impact of $27 \%$ on land use, more than $90 \%$ on total water, blue water, nitrogen, $\mathrm{N}_{2} \mathrm{O}, \mathrm{NH}_{3}$, and $\mathrm{N}$ of Pakistan's total environmental impact. The direct grey water and NOx impacts were both significant, at nearly $78 \%$ and $15 \%$, respectively. Other studies have found somewhat similar high-direct environmental impacts of agriculture in various regions. Agriculture and electricity, for example, accounted for more than $90 \%$ of all direct water use in the United States [68]. Furthermore, agriculture was the largest consumer of water in Spain [31] and the Spanish region of "Castile and León" [34]. According to a recent UNESCO report, agriculture accounts for a significant portion of total nitrate and phosphorus emissions in the OECD countries [69]. According to Almaraz et al., agriculture is the main source of nitrogen oxide emissions in the California region of the United States of America [24]. Finally, the agriculture sector with a value of ' $2428 \mathrm{Gg}^{\prime}$ accounted for almost $1.4 \%$ of Pakistan's 
total sectoral $\mathrm{CO}_{2}$ emissions during the year of 2015. Other studies have indicated that the agricultural (including crop production) sector in general is the largest emitter of $\mathrm{CO}_{2}$ in the global food chain [70]. Agriculture accounted for nearly $1.3 \%$ of total $\mathrm{CO}_{2}$ emissions in the United States in 2018 [71]. Agriculture (including fisheries) accounted for nearly 5.7\% of Pakistan's total energy-related $\mathrm{CO}_{2}$ emissions in 2012 [72]. However, few studies have decomposed the agricultural sector's direct environmental impacts into corresponding inter- and intra-sectoral linkages. According to our findings, downstream sector demand (agricultural product importers) induced nearly 63\% of the agriculture sector's direct environmental impacts, while only $37 \%$ was induced by the agriculture sector's own internal demand. The sectors "Food and Beverage", "Textiles and Wearing Apparel", and "Hotels and Restaurants" were responsible for the majority of these direct environmental impacts.

The agriculture sector's re-imports were primarily responsible for the indirect environmental impacts. However, the majority of the indirect NOx and carbon impacts were embedded in the agriculture sector's imports from upstream suppliers. The related literature does not distinguish between direct and indirect environmental impacts caused by inter- and intra-sectoral imports. Though, related literature has shown that the mixed and upstream linkages induced $\mathrm{CO}_{2}$ emissions of other primary raw material suppliers, such as "mining and quarrying," are also much lower than the downstream and mixed linkages induced emissions [43]. Imports of agricultural products from the sectors of "Financial Intermediation and Business Activities," "Petroleum, Chemical and Non-Metallic Mineral Products," "Transportation," and "Electricity, Gas, and Water" had the highest value of upstream land, water, nitrogen, and $\mathrm{CO}_{2}$ linkages. The agriculture sector's total environmental impact contribution to Pakistan's total sectoral impact was, as expected, quite significant. In particular, the total (direct plus indirect impacts) of agriculture accounted for almost $28 \%, 94 \%, 92 \%$ and $2 \%$ of total land, water, nitrogen and $\mathrm{CO}_{2}$ sectoral impact of Pakistan for the year of 2015. Various studies have previously also shown that agriculture had significant miscellaneous direct and indirect environmental impacts at regional and global levels [26,70,71].

\section{Policy Recommendations}

This section provides general and Pakistan's agriculture sector-specific policy recommendations for the abatement of the agriculture sector's direct and indirect environmental impacts.

The direct environmental impact identifies environmental hazards that are directly related to the sector's operations. The direct environmental impact can be further decomposed into its sources, which can aid in the targeted mitigation of the direct environmental impacts. Our results suggest that Pakistan's agriculture sector's self-consumption of agricultural output did not account for a large portion of its direct environmental impact. Instead, agricultural imports from the downstream sectors were responsible for most of the direct environmental impacts of the agriculture sector. According to our findings, nearly $63 \%$ of the agricultural sector's direct environmental footprints were induced (pulled) by downstream sector demand (agricultural product importers), while only 37\% were induced by the agriculture sector's own internal demand. As a result, in general and particularly in the case of Pakistan's agriculture sector, it is both fair and effective to target downstream demand in addition to the traditional direct efforts aimed at the agriculture sector. The burden of mitigating agriculture's massive direct environmental impacts can thus be distributed. Additionally, without putting too much strain on agriculture, it is possible to achieve sustainable growth in the agricultural sector in order to meet the everincreasing demand for agricultural products. For example, increased efficiency (lower per unit demand) at key downstream agricultural products importers through reduced wastage, recycling, and awareness can contribute to a reduction in the agriculture sector's direct environmental impacts. 
The indirect environmental impact depicts the environmental hazards caused by agricultural sector imports from other sectors. In other words, environmental risks are embedded in agricultural sector inter-sectoral purchases. These linkages are classified as backward (upstream) and mixed. The indirect environmental impacts of the agriculture sector were significantly lower than the direct environmental impacts. However, in order to reduce both the direct and indirect environmental impacts of Pakistan's agricultural sector, these indirect impacts must be considered. The agriculture sector's indirect environmental footprint can be reduced by lowering resource intensity, which is the number of inputs required by the agriculture sector from its upstream suppliers to produce one unit of output. This will help to reduce indirect environmental footprints by requiring fewer resource imports to meet Pakistan's agriculture sector's demand (see [73] for more information on resource productivity/intensity). Furthermore, studies have recommended that upstream suppliers be encouraged (where possible, forced) by downstream buying sectors (industries) to reduce their environmental intensity (the environmental impact per unit of output), which in turn can reduce the indirect environmental impact embedded in the downstream importer's imports [41].

In addition to environmental taxes and credits based solely on direct environmental impacts, policymakers must first consider both direct and indirect environmental impacts. Second, policymakers should consider the main sectoral sources of these direct and indirect environmental impacts when developing agricultural environmental policies. A shared mechanism of environmental impact responsibility for direct and indirect sectoral impacts should be developed in particular. Whereby, a sector, specifically the agriculture sector, may be held accountable for the direct and indirect environmental impacts induced by its consumption, while the agriculture sector's environmental impacts induced by purchases from other sectors should be allocated to the purchasing sectors. According to our decomposition, the agriculture sector, in particular, can be held liable for the indirect environmental impacts caused by its re-imports and imports, as well as the direct environmental impacts caused by intra-sectoral use. On the other hand, agriculture should not be held responsible for the portion of its direct environmental impact caused by imports from downstream buyers. This is because agriculture's direct impact in this case is induced by the consumption (demand) of other sectors and is thus unrelated to agriculture's consumption. However, the fair allocation of sectoral (industrial) environmental impact among different stakeholder groups based on production and/or consumption is a topic of ongoing intense debate in academia [13,74-76]. Supplementary Table S1 compares the method of allocating direct and indirect environmental impacts based on the consumption sector to the traditional allocation based on the production sector for Pakistan's agriculture sector.

Besides the above-mentioned recommendations for the overall reduction of direct and indirect environmental impacts of Pakistan's agriculture sector and the agriculture sector in general, taking into account the economic and social realities of Pakistan, the following land, water, nitrogen and $\mathrm{CO}_{2}$ mitigation actions can be taken by policy makers in Pakistan.

\section{- $\quad$ Land Use}

Keeping in view the significant proportion of the agriculture sector in total sectoral land use in Pakistan, it is necessary for the Pakistani government to increase land productivity. Enhancing land productivity can result in lower input costs and a lower environmental impact from agriculture [77]. Policymakers and farmers in Pakistan should prioritize intensive (industrial) agriculture where a greater proportion of labor and capital should be applied to a given area (portion) of land in order to increase its productivity. Utilizing additional capital to acquire high-efficiency, cutting-edge technologies for cultivation, seed planting, harvesting, and fertilization, among other things, can contribute to Pakistan's agriculture sector's increased productivity. In comparison to conventional extensive agriculture, industrial (intensive) agriculture requires less land to produce the same amount of profit (and output) [78]. However, approximately 60\% of Pakistan's rural population are small farmers [79], and nearly $92.8 \%$ of Pakistan's agricultural farms are marginal (less than 2 hectares) or medium-sized (2-5 hectares) [80] which means that the majority of 
Pakistan's farmers are unable to afford intensive farming. Sustainable intensification of small household agriculture can increase agricultural yields and reduce land demand [80]. Therefore, the Pakistani government must provide substantial financial assistance to small farmers in order to promote sustainable agriculture in Pakistan.

- Water Use

Pakistan is a country that is water-scarce [69]. As per our results, the agriculture sector directly accounted for $93 \%$ of total water (excluding green water footprint), $99 \%$ of blue water and $78 \%$ of grey sectoral water used in Pakistan during 2015. Pakistan is ranked 14th with an extremely high risk of water scarcity [81]. Pakistan's agriculture has a problem in that irrigation is largely based on water-intensive traditional surface irrigation methods. Whereas, nearly $44 \%$ of agricultural land is irrigated via tube wells, the remaining $32 \%, 20 \%$, and $4 \%$ are irrigated via canals, rain, and wells, respectively [82]. This excessive reliance on tube wells for irrigation in Pakistan has resulted in a number of environmental issues, including overuse of underground water, depletion of underground water resources, and lowered underwater quality $[83,84]$. On the other hand, irrigation of agricultural land using water supplied by canals results in approximately $30-40 \%$ water loss (waste), excluding water lost due to field flooding [85]. All of these factors contribute to Pakistan's extremely water-scarce economy's water security risk. Advanced microirrigation techniques such as sprinkler and drip irrigation can be used to maximize the use of Pakistan's scarce water resources. However, there are a number of technical and non-technical barriers preventing Pakistani farmers from adopting these relatively new technologies [86]. As a result, policymakers should prioritize the adoption of cutting-edge irrigation technologies and removing impediments to their adoption in order to foster the development of sustainable agriculture in Pakistan.

- Nitrogen Emissions

Agriculture directly accounted for nearly $92 \%$ of Pakistan's total nitrogen footprint. Additionally, this sector accounted for $91 \%, 99 \%, 15 \%$, and $99 \%$ of Pakistan's $\mathrm{N}_{2} \mathrm{O}, \mathrm{NH}_{3}$, $\mathrm{NOx}\left(\mathrm{NO}+\mathrm{NO}_{2}\right)$, and $\mathrm{N}$ (nitrogen export in water) emissions, respectively. Nitrogen emissions from vehicles and industries can be easily controlled through the use of "end-ofpipe" (point-of-emissions solutions, such as vehicle exhausts) solutions [65]. However, it is extremely difficult to control non-point nitrogen emissions, such as those from agriculture, despite the fact that these non-point emissions account for a significant portion of total nitrogen emissions [65]. There have been several previous treaties signed worldwide to reduce nitrogen emissions [65], but the focus should be on reducing consumption [65]. Here, both direct and indirect consumption reduction strategies can be used to mitigate Pakistan's agriculture sector's nitrogen emissions. Numerous options exist to reduce the agriculture sector's direct consumption and emissions of nitrogen [24]. Improved fertilizer efficiency, mineral fertilizer use, precision fertilization, crop cover, and irrigation strategies, among other things, can all contribute to a reduction in nitrogen consumption and emissions [24]. Indirect consumption reductions can be targeted at industrial and final consumer demand for agricultural products in Pakistan. For instance, increased industrial efficiency and decreased food waste by final consumers, as well as food recycling for animal feed, can all contribute indirectly to the reduction of agricultural sector nitrogen emissions in Pakistan.

\section{- $\mathrm{CO}_{2}$ Emissions}

During 2015, the agriculture sector directly emitted nearly $1.4 \%$ and was indirectly responsible for almost $0.4 \%$ of Pakistan's total $\mathrm{CO}_{2}$ emissions. Tube wells, Pakistan's primary source of irrigation, have an energy efficiency problem [87]. Around $87 \%$ of tube wells in Pakistan are diesel-powered [87]. Pakistani farmers have been forced to use energy-intensive (energy-inefficient) tube well pumps due to a lack of capital [87]. Thus, farmers can be provided with subsidies and low-interest loans to purchase energy-efficient tube wells and water pumps, which will not only reduce costs but also the direct carbon 
emissions and carbon intensity of Pakistan's agriculture sector. Additionally, increasing the efficiency and management of various agricultural equipment used at various stages of the agriculture process can help Pakistan's agriculture sector reduce its direct carbon emissions and intensity. In addition to the above-mentioned measures, organic farming, which has been shown to be environmentally friendly and, in particular, directly improves soil capacity to absorb $\mathrm{CO}_{2}$ emissions [48], should be promoted in Pakistan. At present, very few farmers, due to landlord culture and small farm lands, are practicing organic farming [88]. Therefore, Pakistani fiscal policy makers should consider subsidies and tax reductions (or tax breaks) for farmers practicing or considering eco-friendly agricultural practices like organic farming.

\section{Conclusions}

Agriculture has a significant impact on the environment, which is expected to increase in the future. However, few studies have attempted to estimate the nexus between various environmental impacts and agricultural sector linkages. This study estimated the relationship between the agriculture sector's direct and indirect environmental impacts, as well as inter- and intra-sectoral linkages, using the example of Pakistan's major agriculturebased economy. Additionally, this research proposed a method for decomposing direct and indirect environmental impacts into their inter- and intra-sectoral sources, which has typically not been decomposed (categorized) in prior research. Our findings shed new light on the nexus that exists between agriculture's various environmental impacts and interconnections. The findings indicated that agriculture had a sizable impact on Pakistan's total sectoral environmental impact in terms of land, water, and nitrogen. Agriculture's direct environmental impact was quite significant. The majority of the agricultural sector's direct environmental impact was caused by downstream importers. The agriculture sector's indirect environmental impact, on the other hand, was relatively minor. Re-imports (mixed linkages) contributed significantly to agriculture's indirect environmental impact. Except for $\mathrm{NO}_{\mathrm{X}}$ and $\mathrm{CO}_{2}$ emissions, for which imports from upstream sectors accounted for more than $90 \%$ of these indirect effects. The estimation of different direct and indirect environmental impacts and their intermediate sectoral linkages can help policy makers in general and Pakistani policy makers in particular, to devise policy tools in order to mitigate the ever increasing environmental impacts of the agriculture sector. In particular, policy makers should consider redistributing the mitigation burden of the agriculture sector's environmental impacts based on the intermediate sectoral consumption. Direct environmental impacts from intra-sectoral consumption and indirect environmental impacts from inter-sectoral purchases can be considered for a just and efficient reallocation of environmental impact mitigation in key sectors such as agriculture. Our study has the following uncertainties and limitations. The study is based on the latest available year 2015 IO and environmental accounts data. Furthermore, not all the important direct and indirect environmental impacts of the agriculture sector were estimated in our study. Finally, only a single case was considered. Future studies can, therefore, as new IO data is published in coming years, consider more updated information. Additionally, different environmental impacts like waste, methane $\left(\mathrm{CH}_{4}\right)$, biodiversity loss, etc., can be considered based on the classification system developed in our study for intermediate sectoral environmental linkages. Finally, researchers can also consider regional differences, including those at provincial and national levels, when estimating the nexus between a sector's direct and indirect environmental impacts and linkages.

Supplementary Materials: The following are available online at https:/ / www.mdpi.com/article/10 .3390 /atmos12091200/s1. Table S1: Pakistan's agriculture sector's responsibility for environmental impact, under direct environmental impact versus total environmental impact based on sectoral consumption. Table S2: Pakistan's agriculture sector's direct environmental impacts and sectoral linkages. Table S3: Pakistan's agriculture sector's indirect environmental impacts and sectoral linkages. Table S4: A comparison between the Pakistani agriculture sector and Pakistan's total sectoral environmental impacts. 
Author Contributions: Conceptualization, M.J.S.; formal analysis, M.J.S.; methodology, M.J.S.; writing-original draft, M.J.S.; software, M.J.S.; data curation, M.J.S.; validation, M.H.u.R.; supervision, M.H.u.R.; writing—review and editing, M.H.u.R.; visualization, M.J.S.; project administration, M.H.u.R.; resources, M.H.u.R. All authors have read and agreed to the published version of the manuscript.

Funding: This research received no external funding.

Institutional Review Board Statement: Not applicable.

Informed Consent Statement: Not applicable.

Data Availability Statement: The data for the input-output tables is available on the Eora MRIO website (https: / / worldmrio.com/, accessed on 26 March 2021). All the remaining data is provided in the tables and figures of the main article.

Acknowledgments: The authors would like to thank Zack Wang and three anonymous reviewers for their insightful comments.

Conflicts of Interest: The authors declare no conflict of interest.

\section{References}

1. European Environment Energy. Agriculture and Climate Change; European Environment Energy: Copenhagen, Denmark, 2021.

2. ur Rahman, M.H.; Ahmad, A.; Wang, X.; Wajid, A.; Nasim, W.; Hussain, M.; Ahmad, B.; Ahmad, I.; Ali, Z.; Ishaque, W.; et al. Multi-model projections of future climate and climate change impacts uncertainty assessment for cotton production in Pakistan. Agric. For. Meteorol. 2018, 253-254, 94-113. [CrossRef]

3. Tsangas, M.; Gavriel, I.; Doula, M.; Xeni, F.; Zorpas, A.A. Life cycle analysis in the framework of agricultural strategic development planning in the Balkan region. Sustainability 2020, 12, 1813. [CrossRef]

4. OECD. Agriculture and the Environment. Available online: https://www.oecd.org/agriculture/topics/agriculture-and-theenvironment/ (accessed on 15 July 2021).

5. UNEP. 10 Things You Should Know about Industrial Farming. Available online: https://www.unep.org/news-and-stories/ story /10-things-you-should-know-about-industrial-farming (accessed on 15 July 2021).

6. National Geographic Society Environmental Impacts of Agricultural Modifications. Available online: https://www. nationalgeographic.org/article/environmental-impacts-agricultural-modifications / (accessed on 15 July 2021).

7. WWF Sustainable Agriculture. Available online: https://www.worldwildlife.org/industries/sustainable-agriculture (accessed on 15 July 2021).

8. Rehman, A.; Jingdong, L.; Shahzad, B.; Ali, A.; Hussain, I.; Nabi, G.; Shahid, M. Economic perspectives of major field crops of Pakistan: An empirical study. Pac. Sci. Rev. B Nat. Sci. Eng. 2016, 1, 145-158. [CrossRef]

9. Pakistan Bureau of Statistics Agriculture Statistics. Available online: https://www.pbs.gov.pk/content/agriculture-statistics (accessed on 26 March 2021).

10. Ministry of Finance Agriculure. Pakistan Economic Survey 2017-18; Ministry of Finance, Government of Pakistan: Islamabad, Pakistan, 2019; pp. 13-32.

11. The World Bank. DataBank: World Development Indicators. Available online: https://databank.worldbank.org/source/worlddevelopment-indicators (accessed on 26 March 2021).

12. Sajid, M.J.; Li, X.; Cao, Q. Demand and supply-side carbon linkages of Turkish economy using hypothetical extraction method. J. Clean. Prod. 2019, 228, 264-275. [CrossRef]

13. Sajid, M.J. Inter-sectoral carbon ties and final demand in a high climate risk country: The case of Pakistan. J. Clean. Prod. 2020, 269, 122254. [CrossRef]

14. Eora Global MRIO Eora Documentation: MRIO Structure. Available online: https://worldmrio.com/documentation/ (accessed on 4 September 2021).

15. EPA Agriculture Sectors: Crop (NAICS 111) and Animal (NAICS 112). Available online: https://www.epa.gov/regulatoryinformation-sector/agriculture-sectors-crop-naics-111-and-animal-naics-112 (accessed on 4 September 2021).

16. Schepelmann, P.; Vercalsteren, A.; Acosta-fernandez, J.; Saurat, M.; Maguire, C. Driving Forces of Changing Environmental Pressures from Consumption in the European Food System. Sustainability 2020, 12, 8265. [CrossRef]

17. Industrial Ecology Virtual Laboratory (IELab) Knowledge Base: FREQUENTLY ASKED QUESTIONS ABOUT IOA. Available online: https: / ielab.info/kb/ioa/faq-ioa (accessed on 29 March 2019).

18. WWF. WWF-World Wide Fund for Nature. Available online: https://wwf.panda.org/discover/knowledge_hub/teacher_ resources/webfieldtrips/ecological_balance/eco_footprint/? (accessed on 26 March 2021).

19. Carroll, A. What Is an Environmental Foot Print? (Ecological Footprint). Available online: https://lpelc.org/what-is-anenvironmental-foot-print-ecological-footprint/ (accessed on 26 March 2021).

20. Meribole, J. The Water Crisis in Pakistan. In Borgen Magazine; The Borgen Project: Seattle, WA, USA, 2020. 
21. Food and Agriculture Organization (FAO). FAO in Pakistan: Pakistan at a Glance. Available online: http://www.fao.org/ pakistan/our-office/pakistan-at-a-glance/en/ (accessed on 20 May 2021).

22. Ministry of National Food Security and Research. Agricultural Statistics of Pakistan 2011-12; Ministry of National Food Security and Research: Islamabad, Pakistan, 2013.

23. Lahiani, A. Revisiting the growth-carbon dioxide emissions nexus in Pakistan. Environ. Sci. Pollut. Res. 2018, 25, 35637-35645. [CrossRef] [PubMed]

24. Almaraz, M.; Bai, E.; Wang, C.; Trousdell, J.; Conley, S.; Faloona, I.; Houlton, B.Z. Agriculture is a major source of NOx pollution in California. Sci. Adv. 2018, 4, eaao3477. [CrossRef] [PubMed]

25. Tian, H.; Xu, R.; Canadell, J.G.; Thompson, R.L.; Winiwarter, W.; Suntharalingam, P.; Davidson, E.A.; Ciais, P.; Jackson, R.B.; Janssens-maenhout, G.; et al. A comprehensive quantification of global nitrous oxide sources and sinks. Nature 2020, 586, 248-256. [CrossRef]

26. Desjardins, R.L.; Worth, D.E.; Vergé, X.P.C.; VanderZaag, A.; Janzen, H.; Kroebel, R.; Maxime, D.; Smith, W.; Grant, B.; Pattey, E.; et al. Carbon Footprint of Agricultural Products-A Measure of the Impact of Agricultural Production on Climate Change. In Proceedings of the World AgroMeteorological Information Service, Geneva, Switzerland, 16-17 January 2014. Available online: http:/ / www.wamis.org/agm/meetings/teco14/S5-Desjardins.pdf (accessed on 4 September 2021).

27. Watson, P.R. Animal traction. In Animal Traction; Davis, R., Ed.; Produced for Peace Corps by the TransCentury Corporation, Washington, D. C., under Contract No. 79-043-0129; Peace Corps, Information Collection and Exchange: Washington, DC, USA, 1981.

28. Tongwane, M.; Mdlambuzi, T.; Moeletsi, M.; Tsubo, M.; Mliswa, V.; Grootboom, L. Greenhouse gas emissions from different crop production and management practices in South Africa. Environ. Dev. 2016, 19, 23-35. [CrossRef]

29. Clements, B.J. On the decomposition and normalization of interindustry linkages. Econ. Lett. 1990, 33, 337-340. [CrossRef]

30. Guerra, A.I.; Sancho, F. Measuring energy linkages with the hypothetical extraction method: An application to Spain. Energy Econ. 2010, 32, 831-837. [CrossRef]

31. Duarte, R.; Sa, J.; Bielsa, J. Water use in the Spanish economy: An input-output approach. Ecol. Econ. 2002, 43, 71-85. [CrossRef]

32. Deng, G.; Wang, L.; Xu, X. Linkage effect of virtual water trade in China's industrial products-Based on generalized hypothetical extraction method. Ecol. Indic. 2018, 93, 1302-1310. [CrossRef]

33. Fang, D.; Chen, B. Linkage analysis for water-carbon nexus in China. Appl. Energy 2018, 225, 682-695. [CrossRef]

34. Dionisio, C.; Blanco, P.; Thaler, T. An Input-Output Assessment of Water Productivity in the Castile and León Region (Spain). Water 2014, 6, 929-944. [CrossRef]

35. He, W.; Wang, Y.; Zuo, J.; Luo, Y. Sectoral linkage analysis of three main air pollutants in China's industry: Comparing 2010 with 2002. J. Environ. Manag. 2017, 202, 232-241. [CrossRef] [PubMed]

36. Wang, Y.; Liu, H.; Mao, G.; Zuo, J.; Ma, J. Inter-regional and sectoral linkage analysis of air pollution in Beijing-Tianjin-Hebei (Jing-Jin-Ji) urban agglomeration of China. J. Clean. Prod. 2017, 165, 1436-1444. [CrossRef]

37. Deng, G.; Ma, Y.; Zhang, L.; Liu, G. China's embodied energy trade: Based on hypothetical extraction method and structural decomposition analysis. Energy Sources Part B Econ. Plan. Policy 2018, 13, 448-462. [CrossRef]

38. Sajid, M.J.; Qiao, W.; Cao, Q.; Kang, W. Prospects of industrial consumption embedded final emissions: A revision on Chinese household embodied industrial emissions. Sci. Rep. 2020, 10, 1826. [CrossRef]

39. Sajid, M.J. Structural decomposition and Regional Sensitivity Analysis of industrial consumption embedded emissions from Chinese households. Ecol. Indic. 2021, 122, 107237. [CrossRef]

40. Sun, C.; Chen, L.; Xu, Y. Industrial linkage of embodied CO2 emissions: Evidence based on an absolute weighted measurement method. Resour. Conserv. Recycl. 2020, 160, 104892. [CrossRef]

41. Sajid, M.J.; Qingren, C.; Ming, C.; Shuang, L. Sectoral carbon linkages of Indian economy based on hypothetical extraction model. Int. J. Clim. Chang. Strateg. Manag. 2020, 12, 323-347. [CrossRef]

42. Sajid, M.J.; Cao, Q.; Kang, W. Transport sector carbon linkages of EU's top seven emitters. Transp. Policy 2019, 80, 24-38. [CrossRef]

43. Sajid, M.J.; Shahni, N.; Ali, M. Calculating inter-sectoral carbon flows of a mining sector via hypothetical extraction method. J. Min. Environ. 2019, 10, 853-867. [CrossRef]

44. Sajid, M.J.; Gonzalez, E.D.R.S. The Impact of Direct and Indirect COVID-19 Related Demand Shocks on Sectoral CO2 Emissions: Evidence from Major Asia Pacific Countries. Sustainability 2021, 13, 9312. [CrossRef]

45. Sun, C.; Ding, D.; Yang, M. Estimating the complete $\mathrm{CO}_{2}$ emissions and the carbon intensity in India: From the carbon transfer perspective. Energy Policy 2017, 109, 418-427. [CrossRef]

46. Chen, G.; Hadjikakou, M.; Wiedmann, T. Urban carbon transformations: Unravelling spatial and inter-sectoral linkages for key city industries based on multi-region input-output analysis. J. Clean. Prod. 2017, 163, 224-240. [CrossRef]

47. Tian, X.; Chang, M.; Tanikawa, H.; Shi, F.; Imura, H. Regional Disparity in Carbon Dioxide Emissions Assessing Sectoral Impacts on the Carbon Dioxide Emissions Structure Among Regions of Mainland China. J. Ind. Ecol. 2012, 16, 612-622. [CrossRef]

48. Gomiero, T.; Pimentel, D.; Paoletti, M.G. Environmental Impact of Different Agricultural Management Practices: Conventional vs. Organic Agriculture. CRC Crit. Rev. Plant Sci. 2011, 30, 95-124. [CrossRef]

49. Winstone, B.; Filson, G.; Heck, R.J.; Filho, J.C.D.A. How Organic and Conventional Farmers in Brazil's Natuba Basin understand soil. Agroecol. Sustain. Food Syst. 2019, 43, 409-428. [CrossRef] 
50. Der Werf, H.M.G.; Petit, J. Evaluation of the environmental impact of agriculture at the farm level: A comparison and analysis of 12 indicator-based methods. Agric. Ecosyst. Environ. 2002, 93, 131-145. [CrossRef]

51. Sabiha, N.E.; Salim, R.; Rahman, S.; Rola-Rubzen, M.F. Measuring environmental sustainability in agriculture: A composite environmental impact index approach. J. Environ. Manag. 2016, 166, 84-93. [CrossRef]

52. Dabkiene, V.; Balezentis, T.; Streimikiene, D. Development of agri-environmental footprint indicator using the FADN data: Tracking development of sustainable agricultural development in Eastern Europe. Sustain. Prod. Consum. 2021, 27, 2121-2133. [CrossRef]

53. German, R.N.; Thompson, C.E.; Benton, T.G. Relationships among multiple aspects of agriculture's environmental impact and productivity: A meta-analysis to guide sustainable agriculture. Biol. Rev. 2016, 92, 716-738. [CrossRef]

54. Yue, Q.; Guo, P. Managing agricultural water-energy-food-environment nexus considering water footprint and carbon footprint under uncertainty. Agric. Water Manag. 2021, 252, 106899. [CrossRef]

55. Raliya, R.; Saharan, V.; Dimkpa, C.; Biswas, P. Nanofertilizer for Precision and Sustainable Agriculture: Current State and Future Perspectives. J. Agric. Food Chem. 2018, 66, 6487-6503. [CrossRef] [PubMed]

56. Chiew, Y.L.; Spångberg, J.; Baky, A.; Hansson, P.-A.; Jönsson, H. Environmental impact of recycling digested food waste as a fertilizer in agriculture-A case study. Resour. Conserv. Recycl. 2015, 95, 1-14. [CrossRef]

57. Jiang, Z.; Zheng, H.; Xing, B. Environmental life cycle assessment of wheat production using chemical fertilizer, manure compost, and biochar-amended manure compost strategies. Sci. Total Environ. 2021, 760, 143342. [CrossRef]

58. Fan, W.; Zhang, P.; Xu, Z.; Wei, H.; Lu, N.; Wang, X.; Weng, B.; Chen, Z.; Wu, F.; Dong, X. Life cycle environmental impact assessment of circular agriculture: A case study in Fuqing, China. Sustainability 2018, 10, 1810. [CrossRef]

59. Zhang, X.; Mauzerall, D.L.; Davidson, E.A.; Kanter, D.R.; Cai, R. The Economic and Environmental Consequences of Implementing Nitrogen-Efficient Technologies and Management Practices in Agriculture. J. Environ. Qual. 2015, 44, 312-324. [CrossRef]

60. Ekman Nilsson, A.; Sohn, J.; Vega, G.C.; Birkved, M.; Olsen, S.I. Testing the no agricultural waste concept-An environmental comparison of biorefinery value chains in various regions. Resour. Conserv. Recycl. 2021, 174, 105702. [CrossRef]

61. Zhang, R.; Ma, W.; Liu, J. Impact of government subsidy on agricultural production and pollution: A game-theoretic approach. J. Clean. Prod. 2021, 285, 124806. [CrossRef]

62. Lenzen, M.; Kanemoto, K.; Moran, D.; Geschke, A. Mapping the structure of the world economy. Environ. Sci. Technol. 2012, 46, 8374-8381. [CrossRef] [PubMed]

63. Lenzen, M.; Moran, D.; Kanemoto, K.; Geschke, A. Building Eora: A global multi-regional input-output database at high country and sector resolution. Econ. Syst. Res. 2013, 25, 20-49. [CrossRef]

64. Lenzen, M.; Moran, D.; Bhaduri, A.; Kanemoto, K.; Bekchanov, M.; Geschke, A.; Foran, B. International trade of scarce water. Ecol. Econ. 2013, 94, 78-85. [CrossRef]

65. Oita, A.; Malik, A.; Kanemoto, K.; Geschke, A.; Nishijima, S.; Lenzen, M. Substantial nitrogen pollution embedded in international trade. Nat. Geosci. 2016, 9, 111-115. [CrossRef]

66. Leontief, W.W. Quantitative Input and Output Relations in the Economic Systems of the United States. Rev. Econ. Stat. 1936, 18, 105-125. [CrossRef]

67. Cella, G. The input-output measurement of interindustry linkages. Oxf. Bull. Econ. Stat. 1984, 46, 73-84. [CrossRef]

68. Blackhurst, B.Y.M.; Hendrickson, C.; Engineering, E. Direct and Indirect Water Withdrawals for U.S. Industrial Sectors. Environ. Sci. Technol. 2010, 44, 2126-2130. [CrossRef] [PubMed]

69. WWAP (United Nations World Water Assessment Programme); UN-Water. The United Nations World Water Development Report 2018: Nature-Based Solutions for Water; UNESCO: Paris, France, 2018.

70. Gilbert, N. One-third of our greenhouse gas emissions come from agriculture. Nature 2012, 1-2. [CrossRef]

71. USDA Agricultural Greenhouse Gas Emissions. Available online: https://www.ers.usda.gov/topics/natural-resourcesenvironment/climate-change/ (accessed on 5 September 2021).

72. Mir, K.A.; Purohit, P.; Mehmood, S. Sectoral assessment of greenhouse gas emissions in Pakistan. Environ. Sci. Pollut. Res. 2017, 24, 27345-27355. [CrossRef]

73. Antunes, P. Resource Intensity and Productivity. Available online: http://www.ejolt.org/2012/12/resource-intensity-andproductivity/ (accessed on 25 April 2021).

74. Gallego, B.; Lenzen, M. A consistent input-output formulation of shared producer and consumer responsibility. Econ. Syst. Res. 2005, 17, 365-391. [CrossRef]

75. Steininger, K.W.; Munoz, P.; Karstensen, J.; Peters, G.P.; Strohmaier, R.; Velázquez, E. Austria's consumption-based greenhouse gas emissions: Identifying sectoral sources and destinations. Glob. Environ. Chang. 2018, 48, 226-242. [CrossRef]

76. Lenzen, M.; Murray, J.; Sack, F.; Wiedmann, T. Shared producer and consumer responsibility-Theory and practice. Ecol. Econ. 2007, 61, 27-42. [CrossRef]

77. Ritchie, H.; Roser, M. Land Use. Available online: https://ourworldindata.org/land-use (accessed on 21 April 2021).

78. The Editors of Encyclopaedia Britannica Intensive Agriculture. Available online: https://www.britannica.com/topic/intensiveagriculture/additional-info\#history (accessed on 21 April 2021).

79. Mahmood, K. Pakistan's Bitter Seeds: The Marginalised Small Farmers. Available online: https://nation.com.pk/25-Nov-2019 / pakistan-s-bitter-seeds-the-marginalised-small-farmers (accessed on 4 September 2021). 
80. Hawken, P.; Wilkinson, K.K. Sustainable Intensification for Smallholders. In Drawdown: The Most Comprehensive Plan Ever Proposed to Reverse Global Warming; Hawken, P., Ed.; Penguin Books: London, UK, 2017.

81. Dormido, H. These Countries Are the Most at Risk from a Water Crisis. Available online: https://www.bloomberg.com/graphics/ 2019-countries-facing-water-crisis / (accessed on 4 September 2021).

82. Adnan, M. Adaptation of Modern Irrigation Method Amid Water Shortage. Available online: https://www.technologytimes.pk/ 2020/07/03/adaptation-of-different-irrigation-method-by-farmer-in-current-shortage-of-water/ (accessed on 25 April 2021).

83. Qureshi, A.S.; Gill, M.A.; Sarwar, A. Sustainable groundwater management in Pakistan: Challenges and opportunities. Irrig. Drain. 2010, 59, 107-116. [CrossRef]

84. Qureshi, A.S.; McCornick, P.G.; Sarwar, A.; Sharma, B.R. Challenges and Prospects of Sustainable Groundwater Management in the Indus Basin, Pakistan. Water Resour. Manag. 2010, 24, 1551-1569. [CrossRef]

85. Khan, M.H. Enormous Waste of Water. Dawn. 13 June 2016. Available online: https://www.dawn.com/news/1264520 (accessed on 5 September 2021).

86. Sajid, M.; Tao, L.; Khan, M.I.; Ali, M.; Rehman, S.U. Farmers Perspective Adoption Hindrances of High Efficiency Irrigation Technologies in Punjab-Pakistan. Int. J. Sci. Eng. Res. 2017, 8, 303-314.

87. Qureshi, A.S.; Shah, T.; Akhtar, M. The Groundwater Economy of Pakistan; The Pakistan Country Series No. 19; International Water Management Institute: Lahore, Pakistan, 2003.

88. Panhwar, F. Organic Farming in Pakistan. Available online: https://www.cityfarmer.org/pakistanOrgFarming.html (accessed on 5 September 2021). 